\title{
RELATION BETWEEN THE LEVEL OF HOPE AND FUNCTIONAL RECOVERY AMONG PATIENTS WITH SCHIZOPHRENIA
}

\author{
Amal Sobhy Mahmoud ${ }^{1}$, Soma Ibrahim Ali², Amira Ali Hafez ${ }^{3}$ \\ Professor of psychiatric Nursing and Mental health, faculty of nursing, port said university ${ }^{1}$ \\ Lecturer of psychiatric Nursing and Mental health, faculty of nursing, port said university ${ }^{2}$
}

\begin{abstract}
Background: Schizophrenia is a severe mental disorder interfering with an individual's capacity of clear thinking, managing emotions, making decisions, and relations with others. Aim was to investigate the relation between the hope and functional recovery among patients with schizophrenia. Subjects and method: Design: the study utilized a descriptive correlational research design was used. Setting: psychiatric in patient unit at port said psychiatric health hospital. Tools: The herth hope index (hhi); composed of 12 items adapted version of the herth hope scale (hhs). Tool II: the functional remission of general schizophrenia scale is a 19 items clinician-based questionnaire. In addition, to the demographic and clinical data sheet. Results: there was a statistically significant relation between hope level and the onset of treatment, number of hospitalization. Hope was shown to be significantly linked to gender, age, and family income. There was a statistically significant positive association between hope and functional remission. Conclusion: the study concluded that most of the studied patients have a high level of hope and functional recovery. In addition, it was found that there was a significant positive association between the total score of hope level of schizophrenic patients and the total score of functional recovery. Recommendation: the study recommended that hope-instilling programs and psychological counseling services have to be provided to schizophrenic patients. Moreover, social skills training programs must be carried out for patients with schizophrenia and cooperation with other institutions and organizations has to be achieved for enhancing their levels of professional functioning.
\end{abstract}

Key Words: Functional recovery, Hope, Schizophrenia. 


\section{INTRODUCTION}

Schizophrenia is a severe mental disorder interfering with an individual's capacity of clear thinking, managing emotions, making decisions and relations with other people. It is a complex, long-term disorder. The precise schizophrenia prevalence is challenging to detect, however estimates ranged from $0.25 \%$ to $0.6 \%$ among United States adult persons (Forray \& Buller, 2017).

The estimated lifetime prevalence of schizophrenia is approximately $1 \%$. Schizophrenia is a leading cause of health burdens worldwide (Whiteford et al. 2013) and is one of the greatest mental illnesses as regards human suffering and societal expenditure (Potvin et al. 2008). Schizophrenia has 5 subtypes according to the main symptoms experienced by the patient. A patient's subtype could alter throughout the schizophrenia course (American Psychiatric Association, 2013).

Hope is a power that creates a sense of positive expectation concerning life and permits a person to acknowledge and uses his/her resources in achieving goals (Eizenberg, Ohayon, Yanos, Lysaker \& Roe 2013). Hope is associated with a positive response to therapy and adaptation to therapy in the schizophrenic patients (Kavak \&Yilmaz, 2018).

Hope can motivate the schizophrenic patients to engage in therapy and to promote recovery. Hope ameliorates depression, anxiety, well-being, coping and immunity. Furthermore, it reduces symptoms, improves social functioning, and is associated with better quality of life. The majority of schizophrenic patients are hopeless for many causes including therapy difficulties, being socially stigmatized, incapability of marriage, low social support, as well as economic issues (Dewedar, Harfush \& Gemeay, 2018).

The term "recovery" includes accomplishing levels of social and vocational functioning which are within normal range along with remission of symptoms. Criteria of recovery from schizophrenia include improvement of positive and negative symptoms to a degree that they do not hinder daily activities, and the capacity to live independently regarding caring for self, work or school attendance as well as peer or family relationships (Lahera et al., 2018). 
The model of recovery includes 5 phases which are the moratorium, awareness, preparation, rebuilding and growth. Moratorium is characterized by negative emotions and thoughts including denial, confusion, hopelessness, identity confusion as well as self-protective withdrawal (Wciórka, Świtaj \& Anczewska, 2015).

The nurses have to boost the patient's compliance with therapy through communication with him, hoping to the patient and his/her family. Hope is a significant issue in psychiatric nursing, however no sufficient research exists (Chien, Mui, Gray \& Cheung, 2016).

\section{Significance of the study:}

Schizophrenia is a commonest chronic variety of psychosis in Egypt and represents the bulk of in-patients in mental hospitals (Zahran, Khalil, Okasha, \& Sadek, 2006).The causes of hopelessness in schizophrenia must be documented so that patients feel positive and boost their hope (Coşkun, \& Şahin, 2018). So the aim of this study was to investigate the relation between hope level in patients with schizophrenia and functional recovery. Furthermore, the study will allow a better understanding of hope and functional recovery in schizophrenia therapy and offer important data on this subject for future research.

\section{AIM OF THE STUDY:}

Was to investigate the relation between the hope and functional recovery among patients with schizophrenia.

\section{Research Objectives:}

- Determine the level of hope among schizophrenic patients.

- Assess the functional recovery among schizophrenic patients.

- Explore the relation between the hope, functional recovery levels and demographic, clinical data

- Find out the correlation between the hope and functional recovery among schizophrenic patients. 


\section{SUBJECTS AND METHOD:}

\section{Technical Design:}

The technical design included the study design, study setting, study subjects, sample size, and tools of data collection.

\section{Study Design:}

A descriptive correlational research design was used for the current study.

\section{Study Setting:}

The current study was carried out in Psychiatric inpatient units at Port Said Psychiatric Health Hospital. The hospital is affiliated with the General Secretariat of Mental Health and Addiction Treatment (GSMHAT), Ministry of Health. The hospital provides care to psychiatric and substance abuse patients. The hospital's capacity is 110 beds; serves three Governorates namely Port-Said, El-Ismailia, and El-Suez.

\section{Study Subjects:}

The study subjects was a sample of a patient diagnosed with schizophrenia (males or females) admitted to the inpatient units in Port Said Psychiatric Health Hospital.

\section{Sample Size:}

The study comprised a total of 126 schizophrenic patients who were admitted to the inpatient units in the previously mentioned hospital was included in the study during six months of data collection.

\section{sample tichnique:}

Aconvenient sampling tichnique was being used in current study which include all schizophrinic patients who was attended the inpatient unit in Port said Psychiatric health hospital during the 6 months of data collection.

\section{Tools for Data Collection:}

The study data were collected utilizing the following tools:

\section{Tool I: The Herth Hope Scale (HHI)}

It was firstly developed by Herth (1992) in the English language and translated into Arabic format by the researcher. It incorporates multidimensional features of hope 
and a more global, non-time oriented sense of hope despite of decreased or absent personal relations.

The HHI is 12 items adapted version of the HHI. Items are divided into 3 subscales, (1) Temporality and future, (2) Positive readiness and expectancy, Interconnectedness. Respondents rate each item on a 4-point Likert scale: 1 = strongly disagree, 2 = disagree, 3 = agree, $4=$ strongly agree. To analyze, negative items were reverse scored so that greater scores indicated more hope. Total scores range from 12 to 48 (Haugan, Britt, \& Unni, 2013). The scores were summed, then converted into a percentage

referred to lower hope levels, whereas the score $\geq 60$ were considered as higher hope levels (Karve et al 2009).

\section{Tool II: The Functional Remission Of General Schizophrenia Scale (FROGS)}

It was developed by Llorca, et al. (2009) in the English language. It will be translated into the Arabic language by the researcher. The FROGS total score could be utilized to measure a general construct for the assessment of functional remission. The FROGS includes 19-items clinician-based questionnaire with a highly reliable total score. The factor analysis revealed 3 factors, entitled social functioning (travel and communication, personal activity, social activity, study or work, adaptation to stressful and unforeseen situations, self-esteem and sense of independence, family, peer, love and sex life, social network and empathy and assistance for others), daily life (care and appearance, dietary habit, housekeeping and respect for biological rhythms) and therapy (management of disease and treatment, lack of antisocial or violent behavior, taking charge of personal health and functional effect of secondary impacts of therapy).

\section{Scoring information for the FROGS:}

Precise definitions of all functional domains with behavioral anchor points and an objective description of impairment level have been given. Like all items of FROGS rated over " 3 " mean "do a significant part", we analyzed if the score of 3 multiplied by numbers of items for each of 3 factors of FROGS (i.e. 33 for the 11 items defining the social functioning factor, and12 for the 4 items of daily life, and 12 for the 4 items of the treatment dimension) generated a consistent threshold. Therefore, the functional remission was defined with this instrument as having (at the same time) at least 33 for 
social functioning factor, and at least 12 for the daily life dimension, and at least 12 for the treatment factor. The total score goes from 19 to 95, the greatest scores representing a great functioning level, and lower scores represent lower levels of functioning (Llorca et al., 2009).

The scores were summed and converted into a percentage $<60$ referred to the lower level of functioning, while the score $\geq$ of 60 was considered as the higher level of functioning (Karve et al 2009).

In addition to the demographic and clinical data sheet; this sheet is composed of two parts Demographic data of the studied subjects included age, gender, residence, marriage, work status, educational level, type of current work, number of children, birth order, number of a sibling, family size and persons share the home. Clinical data sheet, which covers the following items: Disease onset, the onset of treatment, number of prior hospital admission, and duration of current hospitalization.

\section{Operational Design:}

It included the preparatory phase, pilot study, validity, reliability and fieldwork.

\section{Preparatory Phase:}

It included reviewing related literature of different aspects of study utilizing books, articles, internet periodicals and magazines to develop the tool for data collection.

\section{Pilot Study:}

It was done to assess the clarity, feasibility and applicability of the tools used for data collection. It was performed before starting the data collection phase on $10 \%$ of the total sample of the hospitalized schizophrenic cases and was carried out from 5/3/2019 to $30 / 3 / 2019$. It was done on 12 schizophrenic patients who attended to the psychiatric inpatient hospital at Port Said Psychiatric Health Hospital and these were ruled out from the total sample of the research work to ensure the stability of the answers. As well, the pilot study provided the investigator experience to deal with patients, familiarity with the setting, and to ensure the time needed to fill in the data collection sheets. Modifications were done accordingly in tools of data collection.

\section{Validity}


The tools were ascertained by an ascertained by a panel of seven professionals in the field of psychiatric medicine and nursing who reviewed the tools for clarity, relevance, comprehensiveness, as well as applicability. They were requested to express their opinions and comments on the translated tools (Tool I and II). The process of translation- retranslation was used to ensure the validity of the translated tools. This phase was carried out in a two months.

\section{Reliability:}

Cronbach's $\alpha$, computed for dichotomous scores was used. A high KR-20 coefficient $(>0.90)$ signifies a homogeneous test. The score for KR-20 range from 0 to 1 , where 0 is no reliability and 1 is perfect reliability.

Assumption and the result: As the KR-20 coefficient is more than 0.95 in these, it is assumed to be homogeneous; for these tools $r=0.774$.

\section{Field Work:}

The researcher started data collection by introducing herself and explaining the aim of the study. Written formal consent was taken from the Ministry of Health \&Population; the General Secretariat of Mental Health and Addiction treatment to carry out the study at Port Said Psychiatric Health Hospital. Written informed consent was taken from all patients before participation. The study tools were then explained to patients and they were reassured that all information will be confidential and utilized only in the current study and they were interviewed separately to keep privacy.

Data was collected in 6 months from April to September 2019. The researcher attended the setting three days/ week on Saturday, Monday and Thursday from 9.00 a.m.to 1.00 p.m., the time spent with each patient was about 60 to 75 minutes, and depended on his response and cooperation. Data were collected from patients (through direct contact with the schizophrenic patients) in inpatient units while the patient is under control. Firstly, the hope level was assessed using the tool I (Herth Hope Index) from the patient himself, then the functional recovery was assessed using tool II (FROGS) from the patient or his next of kin. Clinical data patients underwent checking from the medical charts to be implemented in the tools. Finally, the investigator scored the responses, and compiled them for data analysis.

\section{Administrative Design:}


Before starting any step in the study, an official letter from the Dean of the Faculty of Nursing was sent to the Director of the above-mentioned setting requesting his permission and cooperation to conduct the present research after explaining the study's purpose. Moreover, permission was acquired from the General Secretariat of Mental Health and Addiction Treatment to conduct the study at the Port Said Psychiatric Health Hospital

\section{Ethical Considerations:}

Ethical consideration approval was obtained from the scientific research ethics committee of the faculty of nursing, Port Said University on the $26^{\text {th }}$ of November, 2018. Additionally, approval was obtained from the research ethics committee of the General Secretariat of Mental Health and Addiction Treatment (GSMHAT), Ministry of Health on the $25^{\text {th }}$ of February, 2019. Later, official approval was taken from the hospital administrative authority following explaining the study's purpose. Written consent was taken from each participant or their families before to the beginning of the study. Ethical considerations were maintained through anonymity and confidentiality of the collected data. Besides, voluntary participation and withdrawal ability at any time from the study were highlighted to subjects.

\section{Statistical Design:}

Upon completion of the data collection, collected data was coded, arranged, tabulated and analyzed according to the type of each data by using the SPSS program (IBM SPSS Statistics for Windows, Version 22.0. Armonk, NY: IBM Corp.). Numbers and $\%$ were utilized to express qualitative data. Quantitative data were expressed as means and SD. Qui square test $\left(\mathrm{X}^{2}\right)$ was used to compare qualitative variables. When p-value $\leq 0.05$ a significant level value was measured and a highly significant level value was considered when $\mathrm{p}$-value $\leq 0.001$, but $\mathrm{p}$-value $>0.05$ showed nonsignificant results. 


\section{RESULTS:}

Results revealed that about three quarter of studied patients were males (73.0\%). It was noticed that, the studied patients' ages ranged between 20-65 years with the mean age and S.D of $38.5 \pm 11.5$ years and observed that $46.0 \%$ of the studied patients their age ranges between 20-<35years old. It was found that most of the studied patients were single (61.9\%), 45.2\% are secondary educated. Regarding family income, it was observed that, $52.4 \%$ of patients have enough income. Most of the studied patients $(86.7 \%)$ are a manual workers. The mean and S.D of birth order, is $2.89 \pm 1.8$ of studied patients. The average number of a family members is $5.67 \pm 1.8$. 44.4\% of patients have one of their parents live with them, while, $35.7 \%$ of patients have a sister or brother in the same home. Finally, the average number of rooms in their homes is $2.45 \pm 0.5$.

Clinical characteristics of the studied patients are illustrate that, $57.2 \%$ of patients have a disease onset $1-<15$ with mean and S.D 14.21 \pm 11.0 and the mean onset and S.D of treatment is $13.41 \pm 10.8$. Regarding the number of hospitalization; it shows the mean and S.D is $8.33 \pm 6.5$ times. Also it is observed that, $47.6 \%$ of them stay in hospital for less than one month.

Figure (1): Illustrated distribution of hope level among the studied patients. The majority of studied patients reported (88.9\%) high hope level.

Figure (2): Represent the distribution of functional remission among studied patients, the majority of the studied patients (86.5\%) report high functional remission while, only $13.5 \%$ was a low functional remission.

Table (1): It is observed that, there was a statistically significant positive correlation between total score of hope and the total score of functional remission among studied patients, $\mathrm{p}=0.000^{*}$.

Table (2): Represent the relation between hope level, functional remission level and demographic characteristics among studied patients. There was a statistically significant relation between hope level and gender, age, family income of studied patients. While, the male patient is the highest hope level than females and younger age have a high level of hope than old age. Also, there was a statistically significant 
relation between functional remission level and gender, age, educational level of studied patients.

Table (3): Illustrated that there were a statistically significant relation between hope level and disease onset, the onset of treatment, number of hospitalization and duration of current hospitalization as $\mathrm{P} \leq 0.05$. Also, it represent that, there were a statistically significant relation between functional remission level and disease onset, the onset of treatment, number of hospitalization and duration of current hospitalization as $\mathrm{P} \leq 0.05$.

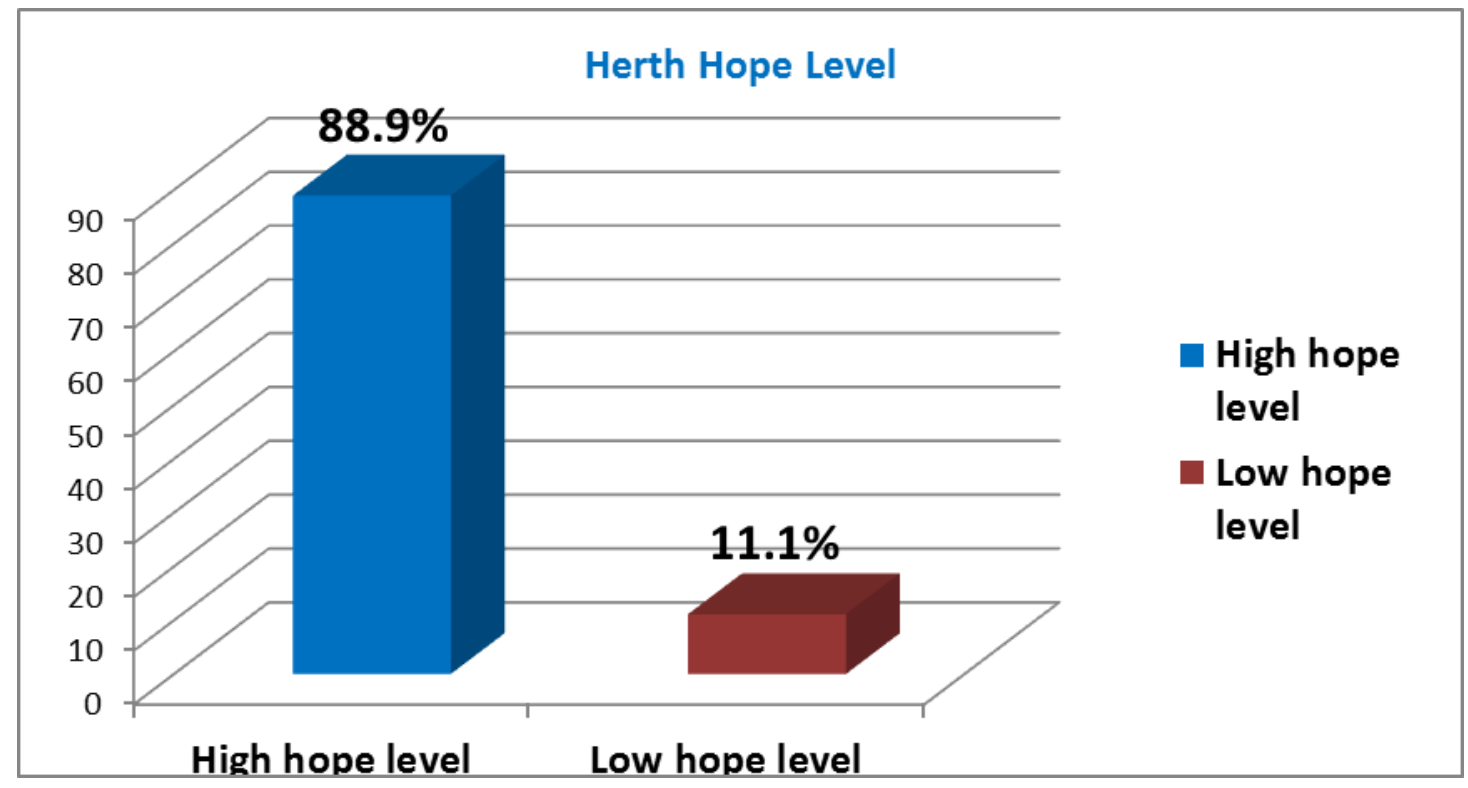

Figure 1: Distribution of hope level among the studied patients $(n=126)$

\section{Functional remission}

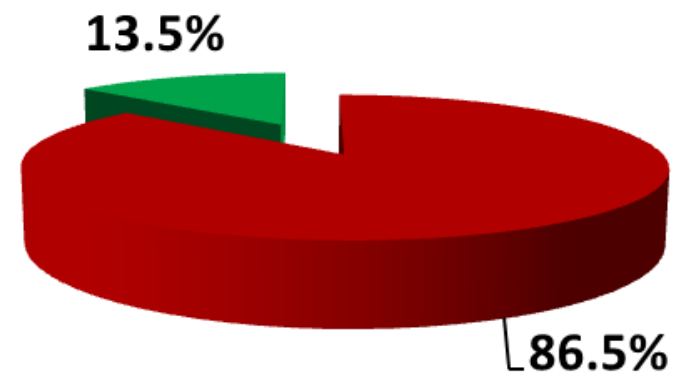

High functional remission

Low functional

remission

Figure 2: Distribution of functional remission among the studied patients $(n=126)$ 
Table 1: Correlation between the total score of hope and functional remission among studied patients

\begin{tabular}{|l|l|l|}
\hline \multirow{2}{*}{ Items } & \multicolumn{2}{|l|}{$\begin{array}{l}\text { The Total score of functional } \\
\text { remission }\end{array}$} \\
\cline { 2 - 3 } & $\mathbf{R}$ & $\mathbf{P}$ \\
\hline The total score of hope & 0.821 & $0.000^{*}$ \\
\hline $\mathbf{r}=$ Pearson correlation & $* *$ Significant at $\mathbf{P} \leq \mathbf{0 . 0 1}$
\end{tabular}

Table 2: Relation between hope level, functional remission level and demographic characteristics among the studied patients $(n=126)$

\begin{tabular}{|c|c|c|c|c|c|c|c|c|c|c|c|c|}
\hline \multirow{3}{*}{ Items } & \multicolumn{4}{|c|}{ Hope level } & \multirow{3}{*}{$\chi^{2}$} & \multirow{3}{*}{\begin{tabular}{|l}
$P$ \\
value
\end{tabular}} & \multicolumn{4}{|c|}{ Functional remission } & \multirow{3}{*}{$\chi_{\text {Test }}^{2}$} & \multirow{3}{*}{$\begin{array}{l}P \\
\text { value }\end{array}$} \\
\hline & \multicolumn{2}{|c|}{$\begin{array}{l}\text { High } \\
\text { n=112 }\end{array}$} & \multicolumn{2}{|c|}{$\begin{array}{l}\text { Low } \\
n=14\end{array}$} & & & \multicolumn{2}{|c|}{$\begin{array}{l}\text { High } \\
\text { n=109 }\end{array}$} & \multicolumn{2}{|c|}{\begin{tabular}{|l|} 
Low \\
$\mathrm{n}=17$ \\
\end{tabular}} & & \\
\hline & \begin{tabular}{|l|} 
No. \\
\end{tabular} & $\%$ & \begin{tabular}{|l} 
No. \\
\end{tabular} & $\%$ & & & \begin{tabular}{|l} 
No. \\
\end{tabular} & $\%$ & No. & $\%$ & & \\
\hline $\begin{array}{l}\text { Gender } \\
\text { Male } \\
\text { Female }\end{array}$ & $\begin{array}{l}82 \\
30\end{array}$ & $\begin{array}{l}73.2 \\
26.8\end{array}$ & $\begin{array}{l}10 \\
4\end{array}$ & \begin{tabular}{l|}
71.4 \\
28.6
\end{tabular} & 0.89 & $0.020 *$ & $\begin{array}{r}79 \\
30 \\
\end{array}$ & $\begin{array}{l}72.5 \\
27.5\end{array}$ & $\begin{array}{l}13 \\
4\end{array}$ & $\begin{array}{l}76.5 \\
23.5\end{array}$ & 11.3 & $0.003 *$ \\
\hline $\begin{array}{l}\text { Age (years) } \\
20-<35 \\
35-<50 \\
50-65\end{array}$ & $\begin{array}{l}56 \\
42 \\
14\end{array}$ & $\begin{array}{l}50.0 \\
37.5 \\
12.5\end{array}$ & $\begin{array}{l}2 \\
7 \\
5\end{array}$ & $\begin{array}{l}14.3 \\
50.0 \\
35.7\end{array}$ & 14.20 & $0.003 *$ & $\begin{array}{l}55 \\
41 \\
13\end{array}$ & $\begin{array}{l}50.5 \\
37.6 \\
11.9 \\
\end{array}$ & $\begin{array}{l}3 \\
8 \\
6\end{array}$ & $\begin{array}{l}17.6 \\
47.1 \\
35.3\end{array}$ & 10.0 & $0.004 *$ \\
\hline $\begin{array}{l}\text { Marital Status } \\
\text { Single } \\
\text { Married } \\
\text { Divorced }\end{array}$ & $\begin{array}{l}69 \\
22 \\
21\end{array}$ & \begin{tabular}{|l|}
61.6 \\
19.6 \\
18.8 \\
\end{tabular} & $\begin{array}{l}9 \\
3 \\
2\end{array}$ & \begin{tabular}{|l|}
64.3 \\
21.4 \\
14.3 \\
\end{tabular} & 0.170 & 0.918 & $\begin{array}{l}66 \\
22 \\
21\end{array}$ & $\begin{array}{l}60.6 \\
20.2 \\
19.2 \\
\end{array}$ & \begin{tabular}{|l}
12 \\
3 \\
2
\end{tabular} & $\begin{array}{l}70.6 \\
17.6 \\
11.8 \\
\end{array}$ & 0.74 & 0.691 \\
\hline $\begin{array}{l}\text { Educational Level } \\
\text { Not read and write } \\
\text { Read and write } \\
\text { Basic education } \\
\text { Secondary education } \\
\text { University education }\end{array}$ & $\begin{array}{l}16 \\
16 \\
22 \\
53 \\
5\end{array}$ & $\begin{array}{l}14.3 \\
14.3 \\
19.6 \\
47.3 \\
4.5\end{array}$ & $\begin{array}{l}4 \\
2 \\
4 \\
4 \\
0\end{array}$ & \begin{tabular}{|l|}
28.6 \\
14.3 \\
28.6 \\
28.6 \\
0
\end{tabular} & 3.673 & 0.452 & $\begin{array}{l}15 \\
15 \\
22 \\
52 \\
5\end{array}$ & $\begin{array}{l}13.8 \\
13.8 \\
20.2 \\
47.7 \\
4.5 \\
\end{array}$ & $\begin{array}{l}5 \\
3 \\
4 \\
5 \\
0\end{array}$ & $\begin{array}{l}29.4 \\
17.7 \\
23.5 \\
29.4 \\
0.0\end{array}$ & 4.37 & $0.042 *$ \\
\hline $\begin{array}{l}\text { Family Income/Month } \\
\text { Enough } \\
\text { Not enough }\end{array}$ & \begin{tabular}{|c}
62 \\
50 \\
\end{tabular} & \begin{tabular}{|c|}
55.4 \\
44.6 \\
\end{tabular} & $\begin{array}{c}4 \\
10 \\
\end{array}$ & \begin{tabular}{|c|}
28.6 \\
71.4 \\
\end{tabular} & 3.58 & $0.058 *$ & $\begin{array}{c}60 \\
49 \\
\end{array}$ & \begin{tabular}{|c|}
55.0 \\
45.0 \\
\end{tabular} & \begin{tabular}{|c}
6 \\
11 \\
\end{tabular} & \begin{tabular}{|c|}
35.3 \\
64.7 \\
\end{tabular} & 2.30 & 0.129 \\
\hline $\begin{array}{ll}\text { Current } & \text { Employment } \\
\text { Status } & \\
\text { Working } & \\
\text { Not working } & \\
\end{array}$ & $\begin{array}{l}82 \\
30 \\
\end{array}$ & \begin{tabular}{|l|}
73.2 \\
26.8 \\
\end{tabular} & $\begin{array}{l}8 \\
6 \\
\end{array}$ & \begin{tabular}{|l|}
57.1 \\
42.9 \\
\end{tabular} & 1.57 & 0.209 & $\begin{array}{l}80 \\
29 \\
\end{array}$ & \begin{tabular}{|l|}
73.4 \\
26.6 \\
\end{tabular} & $\begin{array}{l}10 \\
7 \\
\end{array}$ & \begin{tabular}{|l}
58.8 \\
41.2 \\
\end{tabular} & 1.53 & 0.171 \\
\hline $\begin{array}{ll}\text { Type of } & \text { Current } \\
\text { Work(n=90) } & \\
\text { Manual worker } & \\
\text { Employee } & \end{array}$ & \begin{tabular}{|l|}
72 \\
10 \\
\end{tabular} & \begin{tabular}{|l|}
87.8 \\
12.2 \\
\end{tabular} & $n=8$ & $\begin{array}{l}75.0 \\
25.0 \\
\end{array}$ & 2.42 & 0.298 & $\begin{array}{l}70 \\
10 \\
\end{array}$ & $\begin{array}{l}87.5 \\
12.5 \\
\end{array}$ & $n=10$ & \begin{tabular}{|l}
80 \\
20 \\
\end{tabular} & 1.89 & 0.387 \\
\hline $\begin{array}{l}\text { Number of Children: } \\
\text { Non } \\
1-3 \\
4-6 \\
7 \text { or more }\end{array}$ & \begin{tabular}{|l}
76 \\
28 \\
7 \\
1 \\
\end{tabular} & \begin{tabular}{|l|}
67.9 \\
25 \\
6.3 \\
0.8 \\
\end{tabular} & $\begin{array}{l}11 \\
2 \\
1 \\
0\end{array}$ & \begin{tabular}{|l|}
78.6 \\
14.3 \\
7.1 \\
0 \\
\end{tabular} & 0.95 & 0.814 & $\begin{array}{l}73 \\
28 \\
7 \\
1 \\
\end{array}$ & $\begin{array}{l}67.0 \\
25.7 \\
6.4 \\
0.9 \\
\end{array}$ & \begin{tabular}{|l}
14 \\
2 \\
1 \\
0 \\
\end{tabular} & \begin{tabular}{|l|}
82.4 \\
11.8 \\
5.8 \\
0.0 \\
\end{tabular} & 1.86 & 0.601 \\
\hline $\begin{array}{llll}\text { Number } & \text { of } & \text { Family } \\
\text { Members } & & \\
1-<5 & & \\
5-<10 & & \\
10 \text { or more } & & \\
\end{array}$ & $\begin{array}{l}33 \\
75 \\
4 \\
\end{array}$ & $\begin{array}{l}29.5 \\
66.9 \\
3.6 \\
\end{array}$ & $\begin{array}{l}6 \\
8 \\
0\end{array}$ & \begin{tabular}{|l}
42.9 \\
57.1 \\
0 \\
\end{tabular} & 1.40 & 0.496 & $\begin{array}{l}32 \\
73 \\
4 \\
\end{array}$ & $\begin{array}{l}29.3 \\
67.0 \\
3.7 \\
\end{array}$ & \begin{tabular}{|l}
7 \\
10 \\
0 \\
\end{tabular} & $\begin{array}{l}41.2 \\
58.8 \\
0.0 \\
\end{array}$ & 1.43 & 0.488 \\
\hline
\end{tabular}


Table 3: Relation between hope level, functional remission level and clinical characteristics among studied patients $(n=126)$

\begin{tabular}{|c|c|c|c|c|c|c|c|c|c|c|c|c|}
\hline \multirow{3}{*}{ Items } & \multicolumn{4}{|c|}{\begin{tabular}{|l|} 
Hope level \\
\end{tabular}} & \multirow{3}{*}{$\begin{array}{l}\chi^{2} \\
\text { Test }\end{array}$} & \multirow{3}{*}{$\begin{array}{l}\mathbf{P} \\
\text { value }\end{array}$} & \multicolumn{4}{|c|}{\begin{tabular}{|l|} 
Functional \\
remission
\end{tabular}} & \multirow{3}{*}{$\begin{array}{l}\chi^{2} \\
\text { Test }\end{array}$} & \multirow{3}{*}{$\begin{array}{l}\mathbf{P} \\
\text { value }\end{array}$} \\
\hline & \multicolumn{2}{|c|}{$\begin{array}{l}\text { High } \\
\mathrm{n}=112\end{array}$} & \multicolumn{2}{|c|}{$\begin{array}{l}\text { Low } \\
\mathrm{n}=14\end{array}$} & & & \multicolumn{2}{|c|}{$\begin{array}{l}\text { High } \\
\mathrm{n}=109\end{array}$} & \multicolumn{2}{|c|}{$\begin{array}{l}\text { Low } \\
\mathrm{n}=17\end{array}$} & & \\
\hline & \begin{tabular}{|l|} 
No. \\
\end{tabular} & $\%$ & No. & $\%$ & & & \begin{tabular}{|l|} 
No. \\
\end{tabular} & $\%$ & No. & $\%$ & & \\
\hline $\begin{array}{l}\frac{\text { Disease Onset }}{\text { (years) }} \\
1-<10 \\
10-<20 \\
20-<30 \\
30 \text { or more }\end{array}$ & $\begin{array}{l}58 \\
30 \\
15 \\
9\end{array}$ & \begin{tabular}{|l}
51.8 \\
26.8 \\
13.4 \\
8.0
\end{tabular} & $\begin{array}{l}3 \\
5 \\
3 \\
3\end{array}$ & $\begin{array}{l}21.4 \\
35.8 \\
21.4 \\
21.4\end{array}$ & 5.63 & $0.021 *$ & $\begin{array}{l}56 \\
31 \\
14 \\
8\end{array}$ & $\begin{array}{l}51.4 \\
28.4 \\
12.8 \\
7.4\end{array}$ & $\begin{array}{l}5 \\
4 \\
4 \\
4\end{array}$ & $\begin{array}{l}29.5 \\
23.5 \\
23.5 \\
23.5\end{array}$ & 6.82 & $0.012 *$ \\
\hline 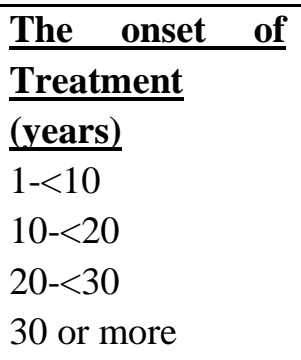 & $\begin{array}{l}60 \\
31 \\
12 \\
9\end{array}$ & $\begin{array}{l}53.6 \\
27.7 \\
10.7 \\
8.0\end{array}$ & $\begin{array}{l}3 \\
6 \\
2 \\
3\end{array}$ & $\begin{array}{l}21.4 \\
42.9 \\
14.3 \\
21.4\end{array}$ & 6.03 & $0.024 *$ & $\begin{array}{l}58 \\
32 \\
11 \\
8\end{array}$ & $\begin{array}{l}53.2 \\
29.4 \\
10.1 \\
7.3\end{array}$ & $\begin{array}{l}5 \\
5 \\
3 \\
4\end{array}$ & $\begin{array}{l}29.4 \\
29.4 \\
17.7 \\
23.5\end{array}$ & 6.47 & $0.013^{*}$ \\
\hline $\begin{array}{l}\text { Number of } \\
\text { Hospitalization } \\
1-<5 \\
5-<10 \\
10-<15 \\
15 \text { or more }\end{array}$ & $\begin{array}{l}50 \\
27 \\
15 \\
20\end{array}$ & $\begin{array}{l}44.6 \\
24.1 \\
13.4 \\
17.9\end{array}$ & $\begin{array}{l}1 \\
2 \\
3 \\
8\end{array}$ & \begin{tabular}{|l|}
7.1 \\
14.3 \\
21.4 \\
57.2
\end{tabular} & 14.05 & $0.003 *$ & $\begin{array}{l}48 \\
27 \\
15 \\
19\end{array}$ & $\begin{array}{l}44.0 \\
24.8 \\
13.8 \\
17.4\end{array}$ & $\begin{array}{l}3 \\
2 \\
3 \\
9\end{array}$ & $\begin{array}{l}17.6 \\
11.9 \\
17.6 \\
52.9\end{array}$ & 12.11 & $0.001^{*}$ \\
\hline $\begin{array}{l}\text { Duration of } \\
\text { Current } \\
\text { Hospitalization }\end{array}$ & $\begin{array}{l}56 \\
41\end{array}$ & \begin{tabular}{|l}
50.0 \\
36.6
\end{tabular} & $\begin{array}{l}4 \\
5\end{array}$ & $\begin{array}{l}28.6 \\
35.7\end{array}$ & 5.10 & $0.035 *$ & $\begin{array}{l}56 \\
40\end{array}$ & $\begin{array}{l}51.4 \\
36.7\end{array}$ & $\mid \begin{array}{l}4 \\
6\end{array}$ & $\begin{array}{l}23.5 \\
35.3\end{array}$ & 10.33 & \\
\hline $\begin{array}{l}\text { Less than one } \\
\text { month } \\
1-<3 \text { months } \\
\text { Long lasting }\end{array}$ & 15 & 13.4 & 5 & 35.7 & & & 13 & 11.9 & 7 & 41.2 & & $0.003 *$ \\
\hline
\end{tabular}

\section{DISCUSSION:}

Schizophrenia is a complex psychiatric disorders with high heritability ranging from 70-90\% (Keshavan, Diwadkar, Montrose, Rajarethinam, \& Sweeney, 2005; Sullivan, Kendler, \& Neale, 2003). Many strategies have been utilized to manage patients, especially using typical and atypical psychoactive. However, due to its multifactorial characteristic and patient resistance, schizophrenia is still a difficult disease to diagnose and treat (Gururajan \& Malone, 2016). 
Over the years, it is understood that the outcome of schizophrenia, should not be measured only in terms of symptomatic improvement. Accordingly, besides symptom remission, many other outcomes such as level of occupational functioning, level of social functioning, level of disability, quality of life, etc, (Grover\& Sahoo, 2020).

Hope is considered to be an important factor in recovering from mental illness (Van Gestel-Timmermans, Van Den Bogaard, Brouwers, Herth, \& Van Nieuwenhuizen, 2010) and is believed to improve the quality of life of people with schizophrenia (Hasson-Ohayon, Kravetz, Meir, \& Rozencwaig, 2009). However, it has been reported that people with schizophrenia have significantly less hope than the general population (Landeen \& Seeman, 2000; Landeen, Pawlick, Woodside, Kirkpatrick, \& Byrne, 2000).

Therefore, the present study was carried out to investigate the relation between the hope and functional recovery among patients with schizophrenia.

The finding of the present study denoted that, it was found that the majority of the studied patients achieved high levels of hope. This may be due to that many of the patients have a family and work, which motivates them to care about treatment and recovery. This result is consistent with Uribe, Bardales, \& Herth, (2012) in Spain who founded that, the total score of hope was fair and their patients were almost hopeful and satisfied.

On the other hand, a study by Barut, Dietrich, Zanoni, and Ridner, (2016); who studied sense of belonging and hope in the lives of persons with schizophrenia, found that more than half of patients described experiences of feeling no hope or hopelessness, severe symptoms of schizophrenia resulted in lack of hope, even to the point of feeling suicidal in many patients. Also, they stated that hope is important to recovery and important to life for persons with schizophrenia.

The study result additionally indicated that, a majority of schizophrenic patients had a high level of hope. This finding can be interpreted to patient who has a high level of hope have a good chance for a good recovery. This finding was in agreement with a study by Uzdil, and Tanriverdi (2015) who studied the effect of psychosocial skills training on functional remission of schizophrenic patients and founded that the total functional remission's score was also high, and that meant that the patients take their 
medication regularly and thus doesn't negatively affect their lives and resulted in a better outcome. Moreover, a study carried out in Turkey by Coşkun, and Altun (2018) about the relationship between the hope levels of patients with schizophrenia, and founded that functional remission's total score was low.

The current work represents that, there was a significant relationship between hope level and gender, the male patient is highest hope level than female. That's may be because Egyptian society is more biased towards men than women, and many parents feel shame if they have female sick with schizophrenia and do not pay more attention to them. This result was supported by the study conducted by, Seeman (2019) and discover that sex differences in outcome thus vary with the patient's age. They also vary with a socio-cultural background of study population. Neither sex, therefore, has a monopoly on a good outcomes. The hope is that studying gender differences will uncover critical elements of good outcomes that lead to interventions that will benefit females and males.

As reported in the current study findings, there was a statistically significant relationship between hope level and age, younger age have a high level of hope than old age. This might be due to the younger age feels that they have a greater chance to achieve their goals toward the future, complete their lives, get a job and start a family than the elderly. This result was supported by the study conducted by Kavak \& Y1lmaz (2018) about the effect of hope on the therapy adherence of schizophrenic patients and founded that hope is a positive feeling that makes the individual acts and feels well and boosts the motivation of persons, prevents feelings of despair and pessimism, and offers positive energy to accomplish goals related to the future.

In the current study, it was revealed that there were a statistical significant relationship between hope levels and disease onset, the onset of treatment, number of hospitalization and duration of current hospitalization. This can be interpreted to the increased awareness of patients and their families about the disease, the importance of early treatment and follow-up, as well as the importance of hope in treatment, which leads to a reduction in the number of hospital readmissions. This finding was in agreement with a study by Lysaker et al., 2005) who studied Hope, awareness of 1llness, coping in schizophrenia spectrum disorders .his Study results indicate that 
there is a decrease in the number of hospitalizations and an increase in treatment compliance rate and quality of life for schizophrenics with high levels of hope .

This interpretation also was agreed with a study that was conducted in Chicago by Haddad et al (2014) who studied non adherence with psychotic medication in schizophrenia,and reported that personal and systemic consequences of antipsychotic drug non adherence include worse symptom severity, increased risk of relapse and hospitalization. Also, in the same line with a study in Europe by Heres, Lambert \& Vauth (2014) who founded that, effective therapy in schizophrenia is important to prevent high risk of relapse after the first psychotic episode.

Furthermore, the current work observed a statistically significant relation between functional remission with disease onset, the onset of treatment, number of hospitalization and duration of current hospitalization. This might be explained that good function recovery appears after treatment compliance and follow up more than one year that's lead also to decrease the number of readmission and decrease also the duration of hospitalization.

Such a result is harmonious with the findings documented by Lappin et al., (2014); Turner et al (2015) who concluded that, a significant relationship between better overall functioning and onset of treatment. Other studies by Alvarez-Jimenez et al (2012); Faerden et al, (2013); Tandberg et al., (2011) who mentioned that, the relation between treatment, number of readmissions to functional remission, found statistic relations between them.

\section{CONCLUSION:}

\section{Based on the findings of the present study, it can be concluded that:}

- It could be concluded that most of the studied patients have a high level of hope and functional remission. Also, it was found that there is a significant positive association between the total score of hope of patients with schizophrenia and functional remission. Hope was shown to be significantly correlated with gender, age, and family income. There is a relation between functional remission level and demographic characteristics among studied patients related to gender, age and educational level. Additionally, a statistically significant relation between functional remission level and disease onset, the onset of treatment, number of hospitalization and also the duration of current hospitalization was illustrated. 


\section{RECOMMENDATIONS:}

In the light of the results of the current study, the following recommendations are suggested:

- Hope-instilling programs and psychological counseling services must be provided to schizophrenic patients.

- Patients must be directed to community mental health centers for ensuring that they continue to receive medical care and boost their levels of functionality.

- $\quad$ Social skills training programs must be carried out for schizophrenic patients.

- Cooperation must be achieved with other institutions and organizations to increase their levels of professional functioning.

\section{REFERENCES:}

Alvarez-Jimenez, M., Priede, A., Hetrick, S. E., Bendall, S., Killackey, E., Parker, A.G., \& Gleeson, J.F. (2012). Risk factors for relapse following treatment for first episode psychosis: A systematic review and meta-analysis of longitudinal studies. Schizophrenia research, 139(1-3), 116-128.

American Psychiatric Association. (2013). Diagnostic and statistical manual of mental disorders (DSM-5®). American Psychiatric Pub.

Barut, J.K., Dietrich, M.S., Zanoni, P.A., \& Ridner, S.H. (2016). Sense of belonging and hope in the lives of persons with schizophrenia. Archives of psychiatric nursing, 30(2), 178-184.

Chien, W.T., Mui, J., Gray, R., \& Cheung, E. (2016). Adherence therapy versus routine psychiatric care for people with schizophrenia spectrum disorders: A randomized controlled trial. BMC psychiatry, 16(1), 42.

Coşkun, E., \& Altun, Ö. Ş. (2018). The relationship between the hope levels of patients with schizophrenia and functional recovery. Archives of psychiatric nursing, 32(1), 98-102. 
Dewedar, A.E.S., Harfush, S.A., \& Gemeay, E.M. (2018). Relationship between insight, self- stigma and level of hope among patients with schizophrenia. IOSR J Nurs Health Sci (IOSR - JNHS), 7(5), 15-24.

Eizenberg, M., Ohayon, I.H., Yanos, P.T., Lysaker, P.H., \& Roe, D. (2013) Internalized stigma and quality of life among persons with severe mental illness: The mediating roles of self-esteem and hope. Psychiatry research, 208(1), 15-20

Forray, C., \& Buller, R. (2017). Challenges and opportunities for the development of new antipsychotic drugs. Biochemical pharmacology,1;143:10-24

Grover, S., \& Sahoo, S. (2020). Outcome measurement in schizophrenia: Challenges and barriers. In Schizophrenia Treatment Outcomes (pp. 91-124). Springer, Cham. Book

Gururajan, A., \& Malone, D. T. (2016). Does cannabidiol have a role in the treatment of schizophrenia? Schizophrenia Research, 176(2-3), 281-290.

Haddad, P. M., Brain, C., \& Scott, J. (2014). Nonadherence with antipsychotic medication in schizophrenia: challenges and management strategies. Patient related outcome measures, 5, 43-62.

Hasson-Ohayon, I., Kravetz, S., Meir, T., \& Rozencwaig, S. (2009). Insight into severe mental illness, hope, and quality of life of persons with schizophrenia and schizoaffective disorders. Psychiatry Research, 167(3), 231-238.

Haugan, G., Utvær, B.K.S., \& Moksnes, U.K. (2013). The Herth Hope Index: A psychometric study among cognitively intact nursing home patients. Journal of Nursing Measurement, 21(3), 378-400.doi: 10.1891/1061-3749.21.3.378.

Heres, S., Lambert, M., \& Vauth, R. (2014). Treatment of early episode in patients with schizophrenia: the role of long acting antipsychotics. European Psychiatry, 29, 1409-1413.

Herth, K. (1992). Abbreviated instrument to measure hope: Development and psychometric evaluation. Journal of Advanced Nursing, 7(10):1251-9. 
Karve S, Cleves MA, Helm M, Hudson TJ, West DS, Martin BC.(2009) Good and poor adherence: optimal cut-point for adherence measures using administrative claims data. Curr Med Res Opin. 2009 Sep;25(9):2303-10.

Kavak, F., \& Y1lmaz, E. (2018). The effect of hope on the treatment adherence of schizophrenia patients. J Turgut Ozal Medic Cent, 25(3), 416-419.

Keshavan, M. S., Diwadkar, V. A., Montrose, D. M., Rajarethinam, R., \& Sweeney, J. A. (2005). Premorbid indicators and risk for schizophrenia: A selective review and update. Schizophrenia research, 79(1), 45-57.

Lahera, G., Gálvez, J. L., Sánchez, P., Martínez-Roig, M., Pérez-Fuster, J. V., García-Portilla, P., \& Roca, M. (2018). Functional recovery in patients with schizophrenia: Recommendations from a panel of experts. BMC psychiatry, 18(1), 176.

Landeen, J., Pawlick, J., Woodside, H., Kirkpatrick, H., \& Byrne, C. (2000). Hope, quality of life, and symptom severity in individuals with schizophrenia. Psychiatric Rehabilitation Journal, 23(4), 364.

Landeen, J., \& Seeman, M. V. (2000). Exploring hope in individuals with schizophrenia. International Journal of Psychosocial Rehabilitation, 5, 45-52.

Lappin, J.M., Morgan, C., Chalavi, S., Morgan, K.D., Reinders, A.A.T. S., Fearon, P., \& Dazzan, P. (2014). Bilateral hippocampal increase following first-episode psychosis is associated with good clinical, functional and cognitive outcomes. Psychological medicine, 44(6), 1279-1291.

Llorca, Pierre-Michel, Christophe Lançon, SylvieLancrenon,Franck- Jean Bayle, Hervé Caci, Frédéric Rouillon, \& PhilipGorwood (2009). The functional remission of general schizophrenia scale: development and validation of a new questionnaire. Schizophrenia Research 113(2), 218-25

Lysaker, P.H., Campbell, K., \& Johannesen, J.K. (2005). Hope, awareness of illness, and coping in schizophrenia spectrum disorders: Evidence of an interaction. The Journal of nervous and mental disease, 193(5), 287-292

Potvin, S., Stip, E., Sepehry, A.A., Gendron, A., Bah, R., \& Kouassi, E. (2008). Inflammatory cytokine alterations in schizophrenia: A systematic quantitative review. Biological psychiatry, 63(8), 801-808. 
Seeman, M. (2019). Does Gender Influence Outcome in Schizophrenia? Psychiatric Quarterly, 90, 173-184.

Tandberg, M., Ueland, T., Sundet, K., Haahr, U., Joa, I., Johannessen, J. O., \& McGlashan, T. (2011). Neuro-cognition and occupational functioning in patients with first-episode psychosis: A 2-year follow-up study. Psychiatry Research, 188(3), 334342.

Turner, N., O'Mahony, P., Hill, M., Fanning, F., Larkin, C., Waddington, J., \& Clarke, M. (2015). Work life after psychosis: A detailed examination. Work, 51(1), 143-152.

Van Gestel-Timmermans, H., Van Den Bogaard, J., Brouwers, E., Herth, K., \& Van Nieuwenhuizen, C. (2010). Hope as a determinant of mental health recovery: A psychometric evaluation of the Herth Hope Index-Dutch version. Scandinavian journal of caring sciences, 24, 67-74.

Uribe, P. M., Bardales, M. C., \& Herth, K. (2012). Propiedades psicométricas de la Escala de Esperanza de Herth en español. Revista Iberoamericana de Diagnóstico y Evaluación-e Avaliação Psicológica, 1(33), 127-145.

Uzdil, N., \& Tanrıverdi, D. (2015). Effect of psychosocial skills training on functional remission of patients with schizophrenia. Western Journal of Nursing Research, 37(9), 1142-1159.

Wciórka, J., Świtaj, P., \& Anczewska, M. (2015). The stages of recovery in relation to the other subjective and objective aspects of psychosis. Psychiatry research, 225(3), 613-618.

Whiteford, H. A., Degenhardt, L., Rehm, J., Baxter, A. J., Ferrari, A. J., Erskine, H. E., \& Burstein, R. (2013). Global burden of disease attributable to mental and substance use disorders: Findings from the global burden of disease study 2010. The Lancet, 382(9904), 1575-1586.

Zahran, N., Khalil, A., Okasha, T., \& Sadek, H., (2006). Systematic review of Egyptian studies on schizophrenia, psychiatry research, unpublished Master desertion, Faculty of Medicine, Ain Shams University. 


$$
\begin{aligned}
& \text { العلاقة بين مستوى الامل والتعافى الوظيفى لاى مرضى الفصام } \\
& \text { أ.د/ أمل صبحى محمود } 1 \text { ، د/ سومة ابراهيم على 2، أميره على حافظ } 3
\end{aligned}
$$

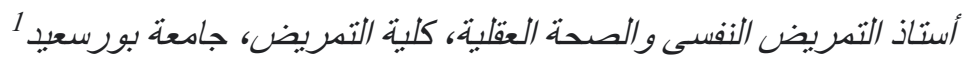

$$
\begin{aligned}
& \text { مدرس التصريض النفسى والصحة العقلية، كلبة التصريض، جامعة بورسعبي² }
\end{aligned}
$$

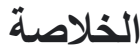

الفصام هو مرض نفسى خطير يتعارض مع قدرة الثخص على التفكير بوضوح و إدارة عواطفه واتخاذ

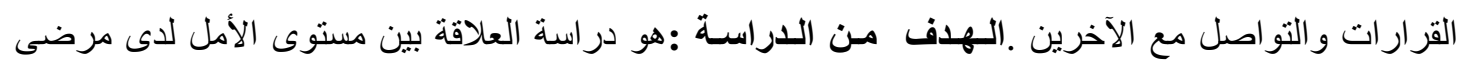

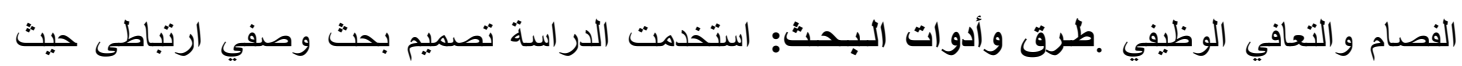

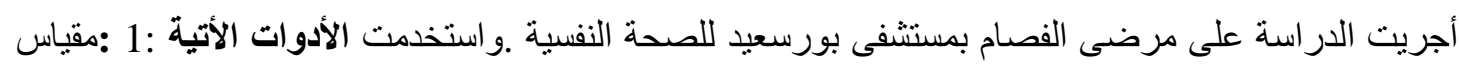

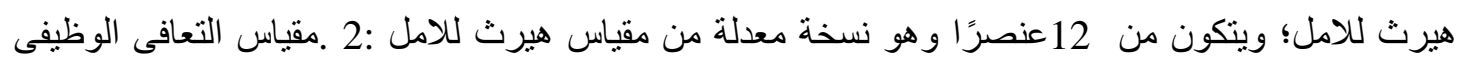

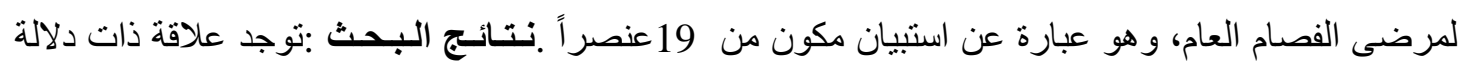
إحصائية بين مستوى الأمل وبداية العلاج، وعدد مرات العودة للمستشفى .وجد أن الأمل مرتبط بشكل كبير

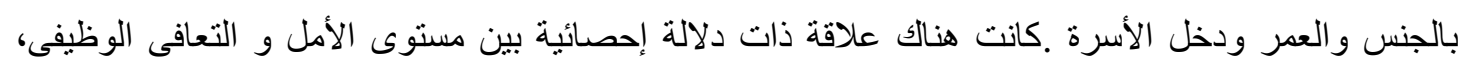

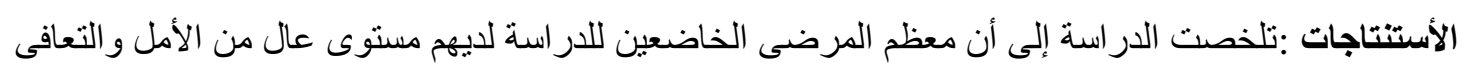

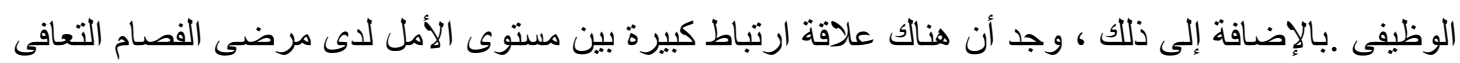
الوظيفي. الكلمات المرشده :الأمـل، الفصـام، التعافـي الوطبفي 